\title{
Assessment of nomadic rice-duck complex ecosystem on energy and economy
}

\author{
Huabin Zheng ${ }^{1,2}$, Huang Huang ${ }^{1,2^{*}}$, Diqin $\mathrm{Li}^{i^{*}}$, Xumeng $\mathrm{Li}^{3}$, Zhiqiang $\mathrm{Fu}^{1,2}$ and Can Chen ${ }^{1,2}$
}

\begin{abstract}
Introduction: Modern intensive rice production has brought a large amount of environmental pollution and do not guarantee the safety of rice quality. Thus, to improve the farmer's rice production model to reduce agro-chemicals is of great importance to decrease pollution and to guarantee the security of food quality. Here, our experiments illustrated that nomadic rice-duck complex ecosystem (RD) could reduce energy input and increase both energy output and the values of the product safety index based on energy (PSI).

Results: According to the results of our experiments, RD and rice monoculture production system (RM) were -0.6 and -0.78 , respectively, which indicated that the safety potential of products in RD was higher than that of RM. Protein yield based on RD was significantly higher than that of RM. The output/input, gross income, and net income of RD were $15.26 \%, 39.51 \%$, and $44.80 \%$, respectively, higher than that of RM; the data suggest that the economic benefits of RD were greater than that of RM.

Conclusions: Consequently, as an intermediate-type technology, RD could become a feasible alternative that could reduce agro-chemical application rate without decreasing rice yield and increasing labor intensity. Furthermore, as an inheritance and development of the Chinese farming culture, RD is a classic Chinese farming technology withstanding more than 700 years of tests.
\end{abstract}

Keywords: Energy; Economy; Intermediate-type technology; Traditional farming technology in China; PSI

\section{Introduction}

Modern agriculture production is a very energy-intensive industry. Fuel and fertilizers ( $\mathrm{N}$ and $\mathrm{P}$ ) account for the largest share $(>75 \%)$ of all energy expenditures in a mixed cropping system (Hetz 1992; Safa and Tabatabaeefar 2002; Ahmad 1994). In the past 50 years, crop yields have substantially increased, mainly resulting from the use of chemical fertilizers and pesticides, the development of new crop varieties, and the improvement in cultivation methods (Xie et al. 2011). However, excessive use of chemical fertilizers and pesticides raised pest resistance toward pesticides and increased the production costs (Paul et al. 2002; Tilman et al. 2002). What is more, their excessive use and misuse, their volatility, and long-distance transports eventually result in widespread environmental

\footnotetext{
* Correspondence: hh863@126.com; Idqhnnd2009@163.com ${ }^{1}$ College of Agronomy, Hunan Agricultural University, Changsha 410128, China

${ }^{2}$ Observation Station of crop cultivation in Central China, Ministry of Agriculture, Changsha 410128, China

Full list of author information is available at the end of the article
}

contamination (Kaushik et al. 2009). In particular, many older, non-patented, more toxic, environmentally persistent, and inexpensive chemicals were extensively used in developing nations, creating serious acute health problems and local and global environmental impacts (Ecobichon 2001). One way to optimize energy consumption in agriculture is to determine the efficiency of methods and techniques used (Bockari-Gevao et al. 2005). Thus, improving the farmer's rice production model to reduce the agro-chemical application rate is of great importance to decrease pollution and guarantee the security of food quality.

Recently, with land circulation system being tried out in China, a large number of small-scale trial farms have been established in the rural areas of southern China (the range of small farm areas is $8 \mathrm{hm}^{2}$ to $100 \mathrm{hm}^{2}$ ), the farm will become the main force of rice production in the future. Continually adopting modern intensive rice production will continually increase the pollution to the environment and cannot guarantee the safety of rice quality. In addition, soil quality in the past 50 years, such as fertility and toxic substances (lead, arsenic), could not 
achieve the standard of organic agriculture. Consequently, there was an urgent need for a feasible alternative between modern intensive agriculture and organic agriculture, which could maintain crop yield, improve soil fertility, and decrease labor intensity. As one of the trial models, riceduck complex ecosystem is one of the traditional farming technologies in China withstanding more than 700 years of tests. Previous studies indicated that rice-duck complex ecosystem was a form of ecological engineering that makes use of the symbiotic relationship between rice and ducks to effectively utilize nutrients, reduce the quantity of chemical fertilizer and pesticide, increase product safety and overall productivity, decrease pollutants discharged from the paddy field (Wang et al. 2004; Zhang et al. 2002), and reduce the emission of greenhouse gas, such as methane (Huang et al. 2000; Huang et al. 2005) and nitric oxide (Zhang et al. 2008; Li et al. 2009).

In this study, energy evaluation method was applied to analyze efficiency of resource utilization and optimize energy consumption. Compared with the rice monoculture production system, ecological and economic effects were evaluated for nomadic rice-duck complex ecosystem.
This work can provide scientific evidence for optimization and promotion of nomadic rice-duck complex ecosystem (RD) as a feasible alternative with reducing energy use and increasing economic benefits without decreasing yields and increasing labor intensity.

\section{Methods}

\section{Study area}

The study area - Changsha Wulong farm - was situated at $28^{\circ} 16^{\prime} \mathrm{N}, 113^{\circ} 63^{\prime} \mathrm{E}$, in the northeast part of Hunan province (see Figure 1). Its arable area was $50 \mathrm{hm}^{2}, 90 \%$ of which was paddy fields. In 2010, it started to convert the mode of production from RM to RD. The soil was yellowish red soil with $\mathrm{pH}=6.6$ to 7.2 and organic matter $=3.0 \%$ to $3.6 \%$, total $\mathrm{N}=2.32 \mathrm{~g} \mathrm{~kg}^{-1}$, total $\mathrm{P}=1.14 \mathrm{~g} \mathrm{~kg}^{-1}$, and total $\mathrm{K}=11.6 \mathrm{~g} \mathrm{~kg}^{-1}$. Its basic climate condition was characterized by annual average sunshine time of $1,700 \mathrm{~h}$, annual average temperature of $17.0^{\circ} \mathrm{C}$, the coldest month (January) has an average temperature of $2.3^{\circ} \mathrm{C}$ and the hottest month (July) an average temperature of $30.1^{\circ} \mathrm{C}$, frost-free period of 280 days, accumulated temperature

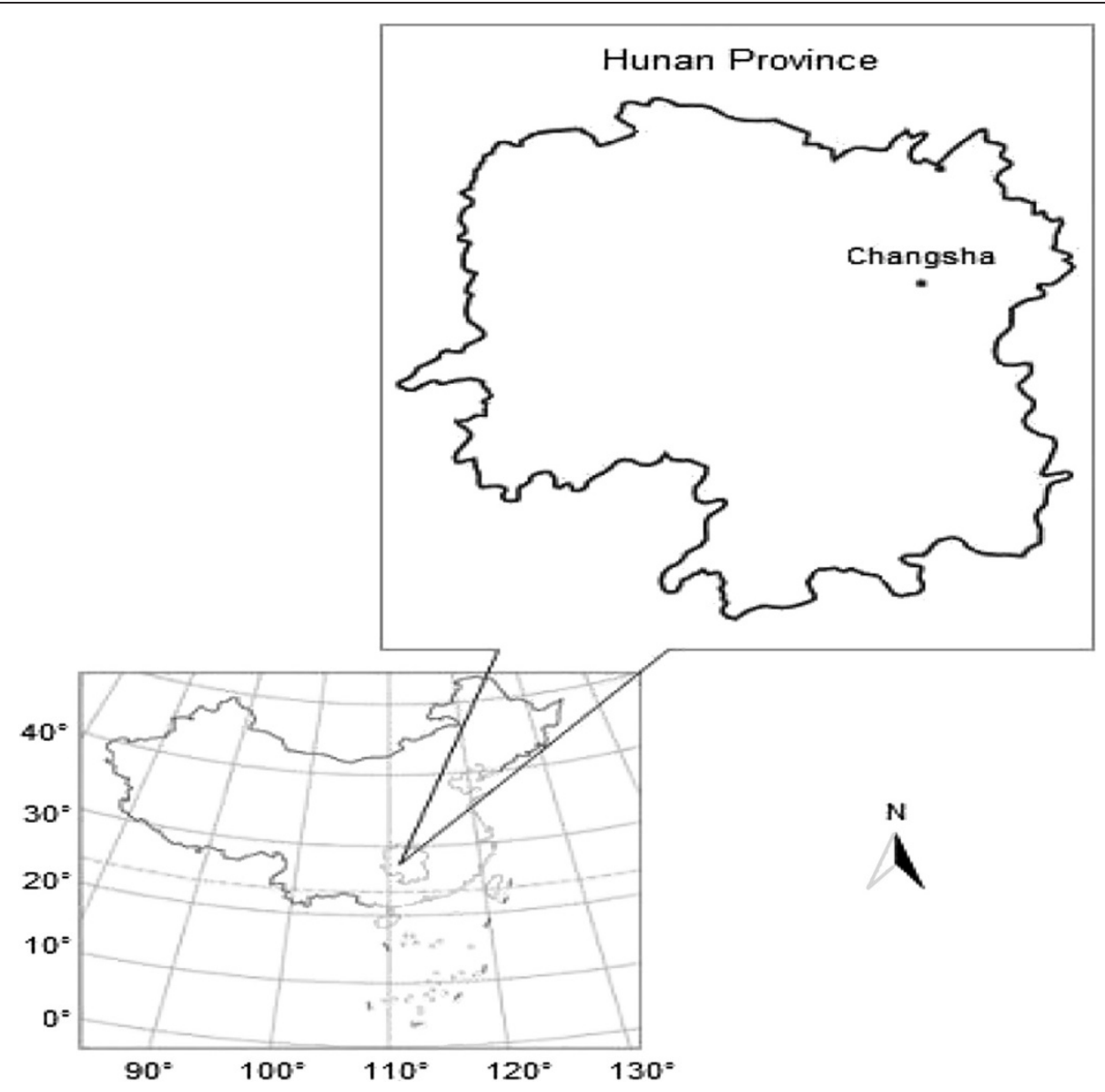

Figure 1 Map of Hunan province in southern-center China. 
$\left(\geq 10^{\circ} \mathrm{C}\right)$ of $5,400^{\circ} \mathrm{C}$, and an average rainfall of $1,450 \mathrm{~mm}$, concentrating in the period from May to September.

\section{Methods}

Quantitative analysis was carried out in a $10-\mathrm{hm}^{2}$ field for the RD, and a $10-\mathrm{hm}^{2}$ field for the RM. Two treatment fields were separated by a fence. Data records of every input and output of these two systems were kept as raw data of energy evaluation and economic assessment. The information on the inputs and outputs of these two rice production systems, including labor (man and woman), fertilizers, diesel, electricity, electric motors, plastics-general, pesticides, fungicides, herbicides, irrigation water, rice seeds, ducklings, feeds (including formula feed and rice grain), rice grain yields, and ducks, were calculated and recorded during the 2010 to 2011 growing season. The energy content, transformity of the materials, and services were based on Table 1; the economic content was based on cash payments of these two rice production systems according to the price during the given years.

The strains of the duck were Jiangnan No. 1 in 2010 and mallard in 2011. From 7 days after transplanting or 15 days after direct seedling to 10 days after flowering stage, the ducks were put in the rice field. A $10 \mathrm{hm}^{2}$ field in the RD was divided into 5 units, the area of every unit was $2 \mathrm{hm}^{2}$; the ducks were shepherded and cruised back and forth in the unit in the paddy field for controlling diseases, pests, and weeds. Every time in the unit was $2 \sim$ 3 days; the ducks got energy through eating weeds and preying on pests in the paddy field, while inputting energy for rice growing through casting of dung. A duckling

Table 1 Energy equivalences for inputs-outputs in the RD and RM

\begin{tabular}{|c|c|c|c|c|c|}
\hline Row & Item & Units & Low-high $^{a}$ & Energy equivalence $^{b}$ & References \\
\hline \multicolumn{6}{|c|}{ Renewable source (R) } \\
\hline 1 & Irrigation & $M J t^{-1}$ & 4.18 & 4.18 & 17 \\
\hline \multicolumn{6}{|c|}{ Renewable organic subsidiary sources (R1) } \\
\hline \multirow[t]{3}{*}{2} & Labor & & & & \\
\hline & Man & $M J h^{-1}$ & 1.96 & 1.96 & 19 to 21 \\
\hline & Woman & $M J h^{-1}$ & 1.57 & 1.57 & 19 to 21 \\
\hline 3 & Rice seed & $\mathrm{MJ} \mathrm{kg}{ }^{-1}$ & 16.74 & 16.74 & 22,23 \\
\hline 4 & Duckling & $M J \mathrm{~kg}^{-1}$ & 10.21 & 10.21 & Estimated \\
\hline \multirow[t]{3}{*}{5} & Feed & & & & \\
\hline & Formulas feed ${ }^{c}$ & $M J \mathrm{~kg}^{-1}$ & 11.68 & 11.68 & Estimated \\
\hline & Rice grain & $M J \mathrm{~kg}^{-1}$ & 14.70 to 16.20 & 15.19 & $17,24,25$ \\
\hline \multicolumn{6}{|c|}{ Nonrenewable industrial subsidiary sources $(F)$} \\
\hline 6 & $\mathrm{~N}$ & $\mathrm{MJ} \mathrm{kg}{ }^{-1}$ & 43.00 to 78.00 & 61.39 & 26 to 32 \\
\hline 7 & $\mathrm{P}_{2} \mathrm{O}_{5}$ & $\mathrm{MJ} \mathrm{kg}{ }^{-1}$ & 11.00 to 17.00 & 14.31 & 26 to 32 \\
\hline 8 & $\mathrm{~K}_{2} \mathrm{O}$ & $\mathrm{MJ} \mathrm{kg}{ }^{-1}$ & 6.00 to 14.00 & 9.40 & 26 to 15 \\
\hline 9 & Diesel & $M J I^{-1}$ & 47.78 to 47.80 & 47.79 & 33,34 \\
\hline 10 & Electric & $\mathrm{MJ} \mathrm{kWh}^{-1}$ & 10.59 to 11.90 & 11.25 & 35,36 \\
\hline 11 & Electric motor & $\mathrm{MJ} \mathrm{kg}{ }^{-1}$ & 64.80 & 64.80 & 19 to 21 \\
\hline 12 & Plastics-general & $\mathrm{MJ} \mathrm{kg}{ }^{-1}$ & 90.00 & 90.00 & Estimated \\
\hline 13 & Insecticide & $\mathrm{MJ} \mathrm{kg}{ }^{-1}$ active agent & 80.00 to 460.00 & 303.25 & 37 to 41 \\
\hline 14 & Herbicides & MJ kg ${ }^{-1}$ active agent & 58.00 to 580.00 & 310.25 & 37 to 41 \\
\hline 15 & Fungicides & MJ kg-1 active agent & 61.00 to 397.00 & 185.00 & 37 to 41 \\
\hline \multicolumn{6}{|c|}{ Output } \\
\hline 16 & Rice grain & $M J ~ \mathrm{~kg}^{-1}$ & 14.70 to 16.20 & 15.19 & $17,24,25$ \\
\hline 17 & Duck & $\mathrm{MJ} \mathrm{kg}{ }^{-1}$ & 10.21 & 10.21 & Estimated \\
\hline
\end{tabular}

${ }^{a}$ Ranges indicate the lowest and highest values found in references; ${ }^{b}$ energy equivalences are taken as the average value of the ranges; ${ }^{\mathrm{c}}$ the composition and nutrition levels of formulas feed: corn $(56.6 \%)$, soybean meal $(15.0 \%)$, rapeseed meal $(3.0 \%)$, wheat bran $(7.5 \%)$, fish meal $(2.0 \%)$, wheat middling $(12.0 \%)$, limestone (1.3\%), $\mathrm{CaHPO}_{4}(1.2 \%), \mathrm{NaCl}(0.3 \%)$, Met (0.1\%), premix (1.0\%), metabolic energy $\left(11.68 \mathrm{MJ} \mathrm{kg}^{-1}\right)$, crude protein $\left(16.68 \% \mathrm{~kg}^{-1}\right) ; 17$, Scott $2000 ; 19$, Mandal et al. 2002; 20, Singh 2002; 21, De et al. 2001; 22, Intaravichai 1998; 23, Rutger and Grant 1980; 24, Mitchell 1979; 25, Pimentel 2009; 26, Kaltcshmitt and Reinhardt 1997; 27, Singh et al. 2002; 28, Pimentel and Pimentel 1979; 29, Leach 1976; 30, Hjortshøj and Rasmussen 1977; 31, Bøckman et al. 1991; 32, Mudahar and Hignett 1987; 33, Hetz 1998; 34, Chamsing et al. 2006; 35, Acaroglu 2002; 36, Pimentel and Pimentel 1996; 37, Pimentel et al. 1996; 38, Anon 2004; 39, Stout et al. 1982; 40, Fluck 1992; 41, Green 1987. 
allowed outside its cage was 7 to 15 days old of breeding. Ducks have an affinity for water; the farmer attracted them to the fields and kept them there long enough to benefit the crop through irrigation in cycles and scattering feed in the field. All procedures performed in studies involving animals were carried out in accordance with the guidelines issued by the Ethical Committee of Hunan Agricultural University.

\section{Main energy and economic indices}

The indices including input energy $\left(E_{\mathrm{i}}\right)$, output energy $\left(E_{\mathrm{o}}\right)$, renewable organic subsidiary sources $(\mathrm{R} 1)$, nonrenewable industrial subsidiary sources $(F)$, net energy gain (NEG), energy ratio $\left(E R=E_{o} / E_{i}\right)$, and energy productivity $\left(\mathrm{EP}=\right.$ rice grain yield $\left./ E_{\mathrm{i}}\right)$. A new index, product safety index based on energy (PSI $=-C /(F+\mathrm{R} 1)$ ), was also suggested to evaluate product safety, which was the negative value of the ratio of energy in chemical pesticides and fertilizers to the total purchased energy and in which $C$ is the sum of chemical fertilizer and pesticide energy (Xi and Qin 2009). In addition, economic indices used were output/input ratio, gross income, and net income.

\section{Statistical analysis of data}

The energy content and transformity of the materials and services are based on Table 1, and the economic content and transformity of the materials and services are based on cash payments of these two systems. Data collected were subjected to analysis of variance. The $F$ test was used to determine significant effects of these two rice production systems, and least significant difference (LSD) was used to separate means. The statistical software used was STATISTLX 8.0.

\section{Results}

\section{Energy analysis}

The energy flows calculated for the two rice production systems are itemized in Tables 2 and 3 . In the RD, the ducks were shepherded to crisscross in the $10 \mathrm{hm}^{2}$ paddy field and they got energy through artificial feeding, eating weeds, and preying on pests in the paddy field, while they released energy for rice through casting of dung and reducing the quantity of fertilizer and pesticides. Rice grain and the ducks were the output energy entering the market. However, in the RM, rice growth and development depend on how much energy is on nonrenewable industrial subsidiary sources, such as inorganic fertilizer and pesticides; rice grain was the output energy entering the market.

Tables 2 and 3 showed that total energy input in RD was 18,607.75 MJ (2010) and 18,482.20 MJ (2011), less than that of RM (19,030.32 MJ for 2010 and 18,904.77 MJ for 2011). We further analyzed the difference of these two rice production systems in the variety of energy input. The ratio of renewable resource, purchased nonrenewable
Table 2 Energy inputs and outputs in the RD (nomadic rice-duck complex system, $\mathrm{MJ} \mathrm{hm}^{-2}$ )

\begin{tabular}{lll}
\hline Item & $\frac{\text { Quantity }}{2010}$ & $\frac{\text { Quantity }}{2011}$ \\
\cline { 2 - 3 } & Input & \\
\hline
\end{tabular}

Renewable source (R)

$\begin{array}{llll}\text { Irrigation water } \quad 600.00 & 2,508.00(6.76)^{a} & 600.00 & 2,508.00(6.76)\end{array}$

Renewable organic subsidiary sources (R1)

Labor

\begin{tabular}{lllll}
\multicolumn{1}{c}{ Man $^{\mathrm{b}}$} & 116.67 & $228.67(0.61)$ & 116.67 & $228.67(0.61)$ \\
\multicolumn{1}{c}{ Woman $^{\mathrm{b}}$} & 174.50 & $273.97(0.24)$ & 174.50 & $273.97(0.24)$ \\
Rice seed & 22.50 & $376.65(2.02)$ & 15.00 & $251.1(1.35)$ \\
$\begin{array}{l}\text { Duckling } \\
{ }^{c}\end{array}$ & 50.00 & $510.5(0.27)$ & 50.00 & $510.50(0.27)$ \\
Feed & & & & \\
Formulas feed $^{\mathrm{d}}$ & 77.70 & $907.54(0.49)$ & 77.70 & $907.54(0.49)$ \\
Rice grain $^{\mathrm{d}}$ & $1,165.50$ & $17,703.95(9.51)$ & $1,165.50$ & $17,703.95(9.51)$
\end{tabular}

Nonrenewable industrial subsidiary sources $(F)$

$\begin{array}{lllll}\mathrm{N} & 135.00 & 8,287.65(44.45) & 135.00 & 8,287.65(44.45) \\ \mathrm{P}_{2} \mathrm{O}_{5} & 63.00 & 901.53(4.84) & 63.00 & 901.53(4.84) \\ \mathrm{K}_{2} \mathrm{O} & 120.00 & 1,128.00(6.06) & 120.00 & 1,128.00(6.06) \\ \text { Diesel } & 63.90 & 3,053.78(16.41) & 63.90 & 3,053.78(16.41) \\ \text { Plastics-general } & 3.40 & 306.00(0.16) & 3.40 & 306.00(0.163) \\ \text { Insecticide } & 0.58 & 175.89(0.95) & 0.58 & 175.89(0.95) \\ \text { Herbicides } & 0.00 & 0.00(0.00) & 0.00 & 0.00(0.00) \\ \text { Fungicides } & 0.00 & 0.00(0.00) & 0.00 & 0.00(0.00) \\ \text { Electric motor } & 6.00 & 388.80(0.21) & 6.00 & 388.80(0.21) \\ \text { Electric } & 32.18 & 362.03(0.19) & 32.18 & 362.03(0.19) \\ \text { Total } & & 18,607.75^{9} & & 18,482.20^{9}\end{array}$

Output

$\begin{array}{lllll}\text { Rice grain } & 5,954.68 & 90,451.59 & 6,187.89 & 93,994.05\end{array}$

$\begin{array}{lllll}\text { Duck }^{\mathrm{e}} \quad 562.50 & 5,743.13 & 562.50 & 5,743.13\end{array}$

Protein $^{f} \quad 573.01 \quad 595.33$

Output: input(MJ) $\quad 4.97^{9} \quad 5.15^{9}$

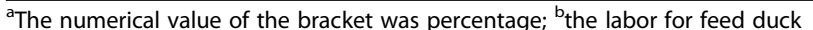
was $65.0 \mathrm{~h}$ of man and $126.5 \mathrm{~h}$ of woman; ' the variety of duckling was farm duck (2010) and mallard (2011); the weight of duckling was the average weight of $50 \mathrm{~g}$; ${ }^{d}$ the quantity of the feed was the quantity for feeding 500 ducks; ${ }^{e}$ the weight of duck was 500 ducks $\times 1.25 \mathrm{~kg} /$ duck(average) $\times 90.00 \%$ (survival ratio) $=562.50$; ${ }^{f}$ the protein content per kilogram was $94.30 \mathrm{~g}$ (rice-duck complex system) of rice grain, $204.10 \mathrm{~g}$ of farm duck and $210.00 \mathrm{~g}$ of mallard; 9 the quantity of the labor for man and woman, duckling, feed, plastics-general, electric motor, electric, and duck share equally to ten copies, which account for energy input in the system.

input, and purchased renewable input to the total energy input were $13.52 \%, 73.37 \%$, and $12.81 \%$ in the RD, respectively, and $13.22 \%, 84.39 \%$, and $2.39 \%$ in the RM, respectively. In the $\mathrm{RD}$, the ratio of purchased renewable inputs was the highest, but in the RM, the highest ratio was that of purchased nonrenewable inputs, which indicated the different feature of the RD and the RM. Total energy output in RD was 91,025.90 MJ (2010) and 94,568.36 MJ 
Table 3 Energy inputs and outputs in the RM (rice monoculture production system, $\mathrm{MJ} \mathrm{hm}^{-2}$ )

\begin{tabular}{|c|c|c|c|c|}
\hline \multirow[t]{3}{*}{ Item } & Quantity & MJ & Quantity & MJ \\
\hline & \multicolumn{2}{|l|}{2010} & \multicolumn{2}{|l|}{2011} \\
\hline & \multicolumn{4}{|l|}{ Input } \\
\hline \multicolumn{5}{|c|}{ Renewable source (R) } \\
\hline Irrigation water & 600.00 & $2,508.00(13.18)^{a}$ & 600.00 & $2,508.00(13.18)$ \\
\hline \multicolumn{5}{|c|}{ Renewable organic subsidiary sources (R1) } \\
\hline \multicolumn{5}{|l|}{ Labor } \\
\hline Man & 51.67 & $101.27(0.27)$ & 51.67 & $101.27(0.27)$ \\
\hline Woman & 24.00 & $37.68(0.10)$ & 24.00 & $37.68(0.10)$ \\
\hline Rice seed & 22.50 & $376.65(1.01)$ & 15.00 & $251.10(1.01)$ \\
\hline Duckling & 0.00 & $0.00(0.00)$ & 0.00 & $0.00(0.00)$ \\
\hline \multicolumn{5}{|l|}{ Feed } \\
\hline Formulas feed & 0.00 & $0.00(0.00)$ & 0.00 & $0.00(0.00)$ \\
\hline Rice grain & 0.00 & $0.00(0.00)$ & 0.00 & $0.00(0.00)$ \\
\hline \multicolumn{5}{|c|}{ Nonrenewable industrial subsidiary sources $(F)$} \\
\hline N & 165.00 & $10,129.35(53.23)$ & 165.00 & $10,129.35(53.58)$ \\
\hline $\mathrm{P}_{2} \mathrm{O}_{5}$ & 63.00 & $901.53(4.74)$ & 63.00 & $901.53(4.77)$ \\
\hline $\mathrm{K}_{2} \mathrm{O}$ & 120.00 & $1,128.00(5.97)$ & 120.00 & $1,128.00(5.97)$ \\
\hline Diesel & 63.90 & $3,053.78(16.05)$ & 63.90 & $3,053.78(16.15)$ \\
\hline Plastics-general & 0.00 & $0.00(0.00)$ & 0.00 & $0.00(0.00)$ \\
\hline Insecticide & 1.38 & 417.27(2.19) & 1.38 & $417.27(2.21)$ \\
\hline Herbicides & 1.13 & $349.03(1.83)$ & 1.13 & $349.03(1.85)$ \\
\hline Fungicides & 0.15 & $27.75(0.15)$ & 0.15 & $27.75(0.15)$ \\
\hline Electric motor & 0.00 & $0.00(0.00)$ & 0.00 & $0.00(0.00)$ \\
\hline Electric & 0.00 & $0.00(0.00)$ & 0.00 & $0.00(0.00)$ \\
\hline Total & & $19,030.32$ & & $18,904.77$ \\
\hline \multicolumn{5}{|l|}{ Output } \\
\hline Rice grain & $5,806.73$ & $88,204.23$ & $6,180.11$ & $93,875.87$ \\
\hline Duck & 0.00 & 0.00 & 0.00 & 0.00 \\
\hline Protein $^{b}$ & 487.18 & & 518.51 & \\
\hline Output : input(MJ) & & 4.63 & & 4.97 \\
\hline
\end{tabular}

${ }^{a}$ The numerical value of the bracket was percentage; ${ }^{b}$ the protein content per kilogram was $83.90 \mathrm{~g}$ (rice monoculture production system) of rice grain.

(2011), higher than that of RM (88,204.23 MJ for 2010 and $93,875.87 \mathrm{MJ}$ for 2011). In the RD, the purchased inputs were dominated by fuel, fertilizer, and feed, accounting for $82.37 \%$; for instance, the energy for feeding duck took $10.72 \%$ of the total energy inputs. By contrast, in RM they were fuel, fertilizer, and pesticides, accounting for $84.39 \%$.

\section{Energy indices}

Chemical residuals and $\mathrm{NO}_{3}$-usage are the main factors to impact the safety of products (Xi and Qin 2009). As shown in Figure 2, the values of PSI in the RD and the RM were -0.60 and -0.78 , respectively; the data suggested that the safety potential of products in the RD was higher than that of RM. There were significant differences at the $5 \%$ level between the treatments on PSI. ER, EP, and energy profitability (PE) in the RD were higher than that of RM, but there were no significant differences at the $5 \%$ level between the treatments on ER, EP, and PE. Human energy profitability (HEP) in the $R M$ was higher than that of $R D$, which suggested that the RD gained yield in paddy field through increased labor intensity but decreased agro-chemical energy, which belonged to labor-intensity farming method, as it conforms to China's national conditions. Protein content of grain based on rice production system in the RD was higher than that of RM, and the difference was significant between the treatments $(p$ value $<0.05)$. 


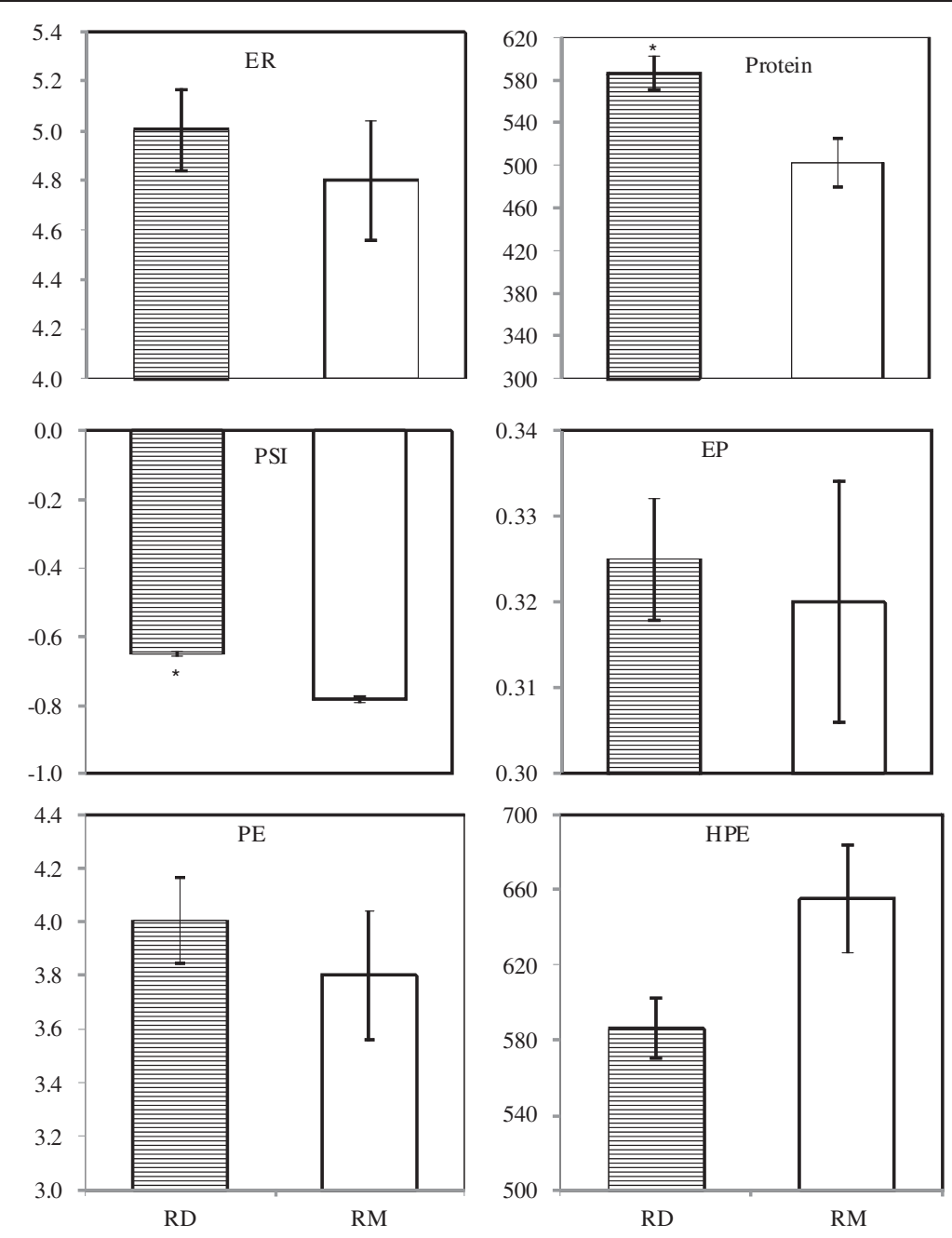

Figure 2 Energy indices in different systems for rice production in Hunan region, China. ${ }^{*}$ represent significance at the 0.05 probability level. ER, energy ratio; PSI, product safety index based on energy; EP, energy productivity; PE, energy profitability; HPE, human energy profitability.

\section{Economic assessment}

As shown in Table 4, total input calculated by China

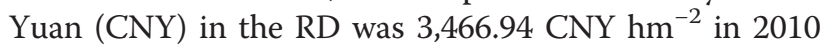
and $3,718.68 \mathrm{CNY} \mathrm{hm}{ }^{-2}$ in 2011, including $22 \%$ to $25 \%$ of the input for feeding ducks and $5 \%$ of the input for pesticides. Total input in the RM was 3,429.81 CNY hm ${ }^{-2}$ in 2010 and $3,566.72 \mathrm{CNY} \mathrm{hm}^{-2}$ in 2011, including about $11 \%$ of the input for pesticides. Total output in RD was 6,685.93 CNY hm $\mathrm{hm}^{-2}$ in 2010 and 7,746.04 CNY hm $\mathrm{hm}^{-2}$ in 2011 , including $10 \%$ to $14 \%$ of the output of duck. The output/input, gross income, and net income in the RD were $15.26 \%, 39.51 \%$, and $44.80 \%$ higher than that of RM, which indicated that the economic benefits of the RD were greater than that of RM.

\section{Discussion}

Agricultural energy consumption has increased largely in response to increasing populations, a limited supply of arable land, and a desire for an increasing standard of living. In all societies, these factors have encouraged an increase in energy inputs to maximize yield, minimize labor-intensive practices, or both (Scott 2000). In China, half of the labor force in the countryside is made up by women accompanied with labor transfer of rural young men, due to the lack of remuneration engaged in planting. However, women could not alone finish rice production based on higher labor intensity. So, what we urgently need is an intermediate-type technology to both increase yields and minimize labor-intensive practice. The input energy of women's labor in RD account for about $60.0 \%$ of total input energy for labor (see Table 2) engaged mainly in looking after and feeding ducks, which belong to low labor-intensive practice. RD was a feasible alternative that could reduce energy use without decreasing rice yield and increasing labor intensity. 
Table 4 Comparison of economic benefits of RD and RM based on money

\begin{tabular}{|c|c|c|c|c|}
\hline & \multicolumn{4}{|c|}{ Economic benefit(CNY hm $\left.{ }^{-2}\right)^{a}$} \\
\hline & \multicolumn{2}{|l|}{ RD } & \multicolumn{2}{|l|}{ RM } \\
\hline & 2010 & 2011 & 2010 & 2011 \\
\hline \multicolumn{5}{|l|}{ 1. Input } \\
\hline Irrigation & 195.00 & 195.00 & 195.00 & 195.00 \\
\hline \multicolumn{5}{|l|}{ Labor } \\
\hline Man & 159.05 & 176.56 & 290.90 & 322.94 \\
\hline Woman & 327.50 & 363.56 & 135.12 & 150.00 \\
\hline Rice seed & 360.00 & 450.00 & 360.00 & 450.00 \\
\hline Duckling & 75.00 & 175.00 & 0.00 & 0.00 \\
\hline \multicolumn{5}{|l|}{ Feed } \\
\hline Formulas feed & 15.54 & 15.54 & 0.00 & 0.00 \\
\hline Rice grain & 116.55 & 124.71 & 0.00 & 0.00 \\
\hline N & 550.80 & 550.80 & 673.20 & 673.20 \\
\hline $\mathrm{P}_{2} \mathrm{O}_{5}$ & 330.75 & 330.75 & 330.75 & 330.75 \\
\hline $\mathrm{K}_{2} \mathrm{O}$ & 612.00 & 612.00 & 612.00 & 612.00 \\
\hline Diesel & 450.50 & 450.50 & 450.50 & 450.50 \\
\hline Insecticide & 180.00 & 180.00 & 235.34 & 235.34 \\
\hline Herbicides & 0.00 & 0.00 & 120.00 & 120.00 \\
\hline Fungicides & 0.00 & 0.00 & 27.00 & 27.00 \\
\hline Electric & 17.70 & 17.70 & 0.00 & 0.00 \\
\hline \multicolumn{5}{|l|}{ 2. Solid cost ${ }^{b}$} \\
\hline Plastics-general & 16.56 & 16.56 & 0.00 & 0.00 \\
\hline Electric motor & 60.00 & 60.00 & 0.00 & 0.00 \\
\hline Total input & $3,466.94$ & $3,718.68$ & $3,429.81$ & $3,566.72$ \\
\hline \multicolumn{5}{|l|}{ 3. Output } \\
\hline Rice grain ${ }^{c}$ & $5,954.68$ & $6,621.04$ & $5,806.73$ & $6,371.51$ \\
\hline Duck $^{d}$ & 731.25 & $1,125.00$ & 0.00 & 0.00 \\
\hline Total output & $6,685.93$ & $7,746.04$ & $5,806.73$ & $6,371.51$ \\
\hline 4. Output/input & 1.93 & 2.08 & 1.69 & 1.79 \\
\hline 5. Gross income & $3,218.99$ & $4,027.36$ & $2,376.92$ & $2,804.79$ \\
\hline \multirow[t]{2}{*}{ 6. Net income } & $2,732.45$ & $3,487.24$ & $1,950.90$ & $2,331.85$ \\
\hline & $+40.0 \%$ & $+49.5 \%$ & - & - \\
\hline
\end{tabular}

${ }^{a_{1} \mathrm{CNY}=0.1571 \mathrm{US} . \$ ;}{ }^{\mathrm{b}}$ the change of plastics-general and electric motor was $82.80 \mathrm{CNY}$ and $300.00 \mathrm{CNY}$, respectively; service life of solid cost was 5 years; cthe wholesale price of rice grain was $1.00 \mathrm{CNY} \mathrm{kg}^{-1}$ in 2010 and $1.07 \mathrm{CNY} \mathrm{kg}^{-1}$ in 2011; ${ }^{d}$ the wholesale price of duck was $10 \mathrm{CNY} \mathrm{kg}^{-1}$ in 2010 and $20 \mathrm{CNY}$ $\mathrm{kg}^{-1}$ in 2011.

More than one in seven people today still do not have access to sufficient protein and energy from their diet and even more suffer from some form of micronutrient malnourishment (Food and Agriculture Organization of the United Nations (FAO) 2009). The duck in the RD could provide meat protein and other micronutrients. Another mission of Chinese or global planting is to guarantee the quality and safety of production by all means. Conventional energy-intensive farming depended on fossil fuel and pesticides, which is not competent now. Effectively changing the structure of purchased energy ratio for the $\mathrm{RD}$, by comparison with RM, can significantly increase PSI and the quantity of protein (see Figure 2). Currently, we could not extend and realize organic farming in a large area, and advanced biotechnology for agriculture has not been used for rice production yet. Consequently, we recommend the RD as an intermediate-type technology to settle this issue.

The economic benefits of rice production seriously affect farmers' enthusiasm for rice production. Low earning in the countryside force farmers to go to the city to make a better living; thus, many farmers have to abandon their farmland. Once farmland is abandoned, the soil is exposed to sun and rain, resulting in erosion and further impoverishment of the soil. The output/ input, gross income, and net income of RD were 15.26, 39.51 , and $44.80 \%$, respectively, higher than that of RM (see Table 4). Adopting the nomadic rice-duck complex ecosystem, to a certain degree, can improve farmers' enthusiasm for rice production.

\section{Conclusions}

(1) RD as an intermediate-type technology is a feasible alternative as it could reduce energy consumption without decreasing rice yield and increasing labor intensity, and as a classic farming technology in China, it was inherited for the development of Chinese farming culture.

(2) RD could reduce energy input, increase energy output, and change the structure of purchased energy ratio. The purchased renewable energy in the RD account for above $25 \%$.

(3) In RD and RM, the values of PSI were -0.60 and -0.78 , respectively, which indicated that the safety potential of products in the RD was higher than that of $\mathrm{RM}$, and protein yield and protein based on system in the $\mathrm{RD}$ were significantly higher than that of RM.

(4) The output/input, gross income, and net income of RD were $15.26,39.51$, and $44.80 \%$, respectively, higher than that of RM; thus, the data suggested that the economic benefits of RD were greater than that of RM.

\section{Abbreviations \\ PSI: product safety index based on energy; RD: nomadic rice-duck complex ecosystem; RM: rice monoculture production system.}

\section{Competing interests}

The authors declare that they have no competing interests.

\section{Authors' contributions}

$\mathrm{HZ}$ carried out the field experiment and recorded raw data of energy evaluation and economic assess, and drafted the manuscript. $\mathrm{HH}$ and DL conceived of the study and participated in its design and coordination. XL, ZF and CC participated in the design of the study and performed the statistical analysis. All authors read and approved the final manuscript. 


\section{Acknowledgements}

We thank Mr. Chen and his wife in Wulong farm who gave a great deal of help to record and collect the study data. We also thank Dr. Huang Min at Hunan Agricultural University for his valuable suggestions on this paper.

\section{Author details}

${ }^{1}$ College of Agronomy, Hunan Agricultural University, Changsha 410128, China. ${ }^{2}$ Observation Station of Crop Cultivation in Central China, Ministry of Agriculture, 410128 Changsha, China. ${ }^{3}$ College of Science, Hunan Agricultural University, Changsha 410128, China.

Received: 9 January 2014 Accepted: 2 September 2014

Published online: 28 October 2014

\section{References}

Acaroglu M (2002) Energy balance sheets in agricultural production-I, Online J Selcuk Tech 2(2):1-18. Konya, Turkey (in Turkish)

Ahmad B (1994) Energetics of major crops in mixed cropping system. AMA 25 (3):52-54

Anon (2004) Appendix C: units, equivalents and energy constants. In: Cooperative Extension Service, Institute of Food and Agricultural Sciences, University of Florida.

Bockari-Gevao SM, Wan Ishak WI, Azmi Y, Chan CW (2005) Analysis of energy consumption in lowland rice-based cropping system of Malaysia. Songklanakarin J Sci Technol 27(4):819-826

Bøckman OC, Kaarstad O, Lie OH (1991) Landbruk oggjødsling, Mineralgjødsling iperspektiv, Agriculture and fertilisation. Mineral fertilisation in perspective. Norsk Hydro, Oslo, p 248. ISBN 82-90861-01-x

Chamsing A, Salokhe V, Singh G (2006) Energy consumption analysis for selected crops in different regions of Thailand. Agric Eng Int: CIGRE J Manuscript EE 06013. Vol. VIII. November

De D, Singh S, Chandra H (2001) Technological impact an energy consumption in rainfed soybean cultivation in Madhya Pradesh. Appl Energy 70:193-213

Ecobichon DJ (2001) Pesticide use in developing countries. Toxicology 160(1-3):27-33

Fluck RC (1992) Energy in farm production. Elsevier, Amsterdam, p 367. ISBN $0-444-88681-8$

Food and Agriculture Organization of the United Nations (FAO) (2009) State of food insecurity in the world., FAO, Rome, 2009

Green M (1987) Energy in pesticide manufacture, distribution and use. In: Helsel ZR (ed) Energy in Plant Nutrition and Pest Control, Vol. 7. Elsevier, Amsterdam, pp 165-177. ISBN 0-444-42753-8

Hetz E,J (1992) Energy utilization in Chilean Agriculture. AMA 23(2):25-26

Hetz EJ (1998) Energy utilization in fruit production in Chile. Agric Mech Asia Africa Latin America (AMA) 298(2):17-20

Hjortshøj A, Rasmussen S (1977) Enkortlægning af den primære jordbrugssektors energy iforbrug (Mapping the energy use of the primary sector), vol Report no. 7. Økonomisk Institut, Den Kongelige Veterinær-og Landbohøjskole, Copenhagen, $\mathrm{p} 119$

Huang $\mathrm{H}$, Yang ZH, Wang H, Hu ZY, Chen SG, Chen C (2000) A study on the pattern of methane emission in wetland rice-duck complex ecosystems. Acta Ecologica Sinica 23(5):929-934

Huang Y, Wang H, Huang H, Feng ZW, Yang ZH, Luo YC (2005) Characteristics of methane emission from wetland rice-duck complex ecosystem. Agric Ecosystems Environ 105:181-193

Intaravichai P (1998) Energy analysis in mechanised rice production system: specifically for Central Thailand, PhD dissertation. Universiti Putra Malaysia, Malaysia

Kaltcshmitt M, Reinhardt GA (1997) Ecological energy balance sheets in renewable energy source. Friedr. Vieweg, Sohn Verlagsgesellschaft mbH, Braunschweig, Weisbaden, Germany, in German

Kaushik G, Satya S, Naik SN (2009) Food processing a tool to pesticide residue dissipation - a review. Food Res Int 42:26-40

Leach G (1976) Energy and food production. IPC Science and Technology Press Limited, Guilford, Surrey, p 151

Li CF, Cao CG, Wang JP, Zhan M, Yuan WL, Ahmad S (2009) Nitrous oxide emissions from wetland rice-duck cultivation systems in Southern China. Arch Environ Contam Toxicol 56:21-29

Mandal KG, Saha KP, Gosh PL, Hati KM, Bandyopadhyay KK (2002) Bioenergy and economic analyses of soybean-based crop production systems in central India. Biomass Bio-energy 23:337-45
Mitchell R (1979) An analysis of India agro-ecosystem. Interprint, New Delhi, India, 180

Mudahar MS, Hignett TP (1987) Energy requirements, technology and resources in fertilizer sector. In: Helsel ZR (ed) Energy Plant Nutrition and Pest Control: Energy in World Agriculture, Vol. 2. Elsevier, Amsterdam, pp 25-61

Paul M, Fließbach A, Dubois D, Gunst L, Fried P, Niggli U (2002) Soil fertility and biodiversity in organic farming. Science 296:1694-1697

Pimentel D (2009) Energy input in food crop production in developing and developed nations. Energies 2:1-24

Pimentel D, Pimentel M (1979) Food, energy and society. Resource and environmental science series. Edward Arnold, London

Pimentel D, Pimentel M (1996) Food, energy, and society. University Press of Colorado,

Pimentel D, Houser J, Preiss E, White O, Fang H, Mesnick L, Barsky T, Tariche S, Schreck J, Alpert S (1996) Water resources: agriculture, the environment, and society. Bio Science 47(2):97-106

Rutger JN, Grant WR (1980) Energy use in rice production. In: Pimentel D (ed) Handbook of energy utilization in agriculture. CRC Press, Inc, Boca Raton, Florida, p 475

Safa M, Tabatabaeefar A (2002) Energy consumption in wheat production in irrigated and dry land farming. In: Proc. Intl. Agric. Engg. Conf., Wuxi, China, Nov. 28-30, 2002

Scott K (2000) Energy use in American agriculture, Sustainable energy term paper., pp 1-26

Singh JM (2002) On farm use pattern in different cropping systems in Haryana, India. Dissertation for master thesis. International Institute of Management, University of Flensburg, Germany

Singh H, Mishra D, Nahar NM (2002) Energy use pattern in production agriculture of a typical village in arid zone, India-part-I. Energy Convers Manage 43:2275-86

Stout BA, Myers C, Schwab G (1982) Energy management in US production agriculture. In: Robinson DW, Mollan RC (eds) Energy Management and Agriculture, vol 5. Royal Dublin Society, Dublin, pp 67-84

Tilman D, Cassman KG, Matson PA, Naylor R, Polasky S (2002) Agricultural sustainability and intensive production practices. Nature 418:671-677

Wang QS, Huang PS, Zhen R, Jing L, Tang H, Zhang C (2004) Effect of rice-duck mutualism on nutrition ecology of paddy field and rice quality. Chin J Appl Ecol 25(4):639-645

Xi YG, Qin P (2009) Energy evaluation of organic rice-duck mutualism system. Ecol Eng 35:1677-1683

Xie J, Hu LL, Tang JJ, Wu X, Li NN, Yuan YG, Yang HS, Zhang JE, Luo SM, Chen X (2011) Ecological mechanisms underlying the sustainability of the agricultural heritage rice-fish co-culture system. Proc Natl Acad Sci U S A 108(47):1-7

Zhang JE, Lu JX, Zhang GH, Luo SM (2002) Study on the function and benefit of rice-duck agro-ecosystem. Ecol Sci 21(1):6-10

Zhang JE, Ouyang Y, Huang ZX (2008) Characterization of nitrous oxide emission from a rice-duck farming system in South China. Arch Environ Contam Toxicol 54:167-172

\section{doi:10.1186/s13717-014-0020-y}

Cite this article as: Zheng et al: Assessment of nomadic rice-duck complex ecosystem on energy and economy. Ecological Processes 2014 3:20.

\section{Submit your manuscript to a SpringerOpen ${ }^{\odot}$ journal and benefit from:}

- Convenient online submission

$\checkmark$ Rigorous peer review

- Immediate publication on acceptance

- Open access: articles freely available online

- High visibility within the field

- Retaining the copyright to your article

Submit your next manuscript at $\boldsymbol{\wedge}$ springeropen.com 